\title{
Democratic Freedom of Expression
}

\author{
Ricardo Restrepo \\ Centro de Derechos y Justicia, Instituto de Altos Estudios Nacionales, Quito, Ecuador \\ Email: ricardo.restrepo@iaen.edu.ec, ricardo.restrepo28@yahoo.co.nz
}

Received May $7^{\text {th }}$, 2013; revised June $7^{\text {th }}$, 2013; accepted June $14^{\text {th }}$, 2013

\begin{abstract}
Copyright (c) 2013 Ricardo Restrepo. This is an open access article distributed under the Creative Commons Attribution License, which permits unrestricted use, distribution, and reproduction in any medium, provided the original work is properly cited.
\end{abstract}

\begin{abstract}
This paper suggests the democratic direction in which the right of freedom of expression should be conceived and applied. In the first two sections it suggests some counter-examples to, and diagnoses of, the libertarian and liberal conceptions of freedom of expression, taking Scanlon (1972) and Scanlon (1979), respectively, to be their chief proponents. The paper suggests that these conceptions cannot take into account clear examples, like fraudulent propaganda, which should not be legal. The democratic conception takes it to heart that the pillars upon which the right of freedom of expression is founded are individual and collective autonomy, the right to know facts of public interest and information necessary for effective democratic control of government. The paper suggests that in a time when private powers seriously threaten these pillars, it is correct for the government to step in to provide the framework in which genuine discussion geared toward fulfilling the objectives of these pillars can take place.
\end{abstract}

Keywords: Freedom of Expression; Media; Libertarianism; Liberalism; Democracy

\section{Introduction}

The right to freedom of expression and the democratic system have a directly proportional relationship. Through the exercise of this right we are able to decide who we are, to speak our minds, get information, cast our vote, shape government and hold it to account, and influence our environment so that it becomes the kind of place we wish to lead our lives in. A place in which these things happen is a democracy - and in turn, the democratic system provides the social, political and economic conditions for this right to be effectively exercised. ${ }^{1}$ If you make the system more democratic, you increase the effective capacity of individuals to exercise their right to freedom of expression of individuals, and conversely, if you increase the effective capacity for individuals to exercise their right to freedom of expression you create a more democratic system - otherwise, you might have a democratic society only in pretty proclamations. There cannot be democracy without freedom of expression and there is no freedom of expression where there is no democracy. In this sense, individual freedom of expression rights and democracy have fractal structures, where the micro and macro structures reflect one another. While the right of freedom of expression involves the right of freedom of artistic expression and academic freedom, for instance, the central interest in this paper is on media freedom.

The democratic analysis of the right of freedom of expression may sound fairly trite, standard, and even, perhaps, conservative. Could the right of freedom of expression be conceived otherwise than as democratic? It is within a framework

${ }^{1}$ Braddon-Mitchell and West (2004) think of free speech as a property more properly thought to pertain to communities rather than to individuals, though this paper does not imply that freedom of expression is exclusively individualistic or social. The social way of thinking of freedom speech is also seen in Fiss (1986). of democratic values that, in my view, the right of freedom of expression makes unique sense and this paper aims to make this claim more precise, cogent and differentiated from alternative libertarian and liberal conceptions. I apply a fairly uncontroversial conception of the proper functions of the right of freedom of expression, to two concrete cases of international controversy: Julian Assange and Wiki Leaks, and Correa v. Palacio and El Universo. Independent of avowed adherence to democracy, supposed bastions of the right of freedom of expression in society such as some major human rights NGO's, states and the major mass media turn out to be defending undemocratic positions - undermining the authentic right of freedom of expression in society.

Crucial underlying functions of the right of freedom of expression, in terms of which this right acquires value, are achieving individual and collective autonomy, informed democratic control of government by the people and the right to know facts of public interest. ${ }^{2}$ Securing the realization of such values furthers the cause of the abolition of domination, while extending the exercise of freedom of expression to the point where it becomes an act of domination is to extend it beyond the sphere in which this freedom is a right. ${ }^{3}$ The same happens with the freedom of movement (Art. 13 of The Universal Declaration of Human Rights) - it is a right until the point at which, without reason, my fist impacts someone's nose. The right of freedom of expression defines a scope for this freedom-it is the scope in which freedom is (at least) not unjust. The libertarian and liberal conceptions of freedom of expression hold a version of the doctrine that the content of any expression is

${ }^{2}$ I take such values to be shared in the discussion of freedom of expression at least from Mill (1789/1975) onwards.

${ }^{3}$ This paper, while opting for several departures, gathers inspiration from the democratic justice of Ian Shapiro and republicanism of Philip Pettit, found in Shapiro (2003a; 2003b; 2011; 2012) and Pettit (1997; 2009). 
sacrosanct, in that it is to be unlimitedly protected from government intervention, independent of whether it is false or leads to harmful consequences. At a fundamental level, these views seem to employ a kind undue apriorism by wrongly assuming that a lack of lawful state regulation is the best way to uphold the features in terms of which the right of freedom of expression is valuable-unreflectingly assuming that the scope of all possible contents of expression is the scope of expression considerations of justice can legitimize.

The aforementioned apriorism about norms these concepttions imply fails to centrally take into consideration specific ways in which private power, a power very present in our times, may undermine the right of freedom of expression. The apriorism can be diagnosed to fall prey to what Anthony Coady (2008) calls "absolutist moralism" and "moralism of unbalanced focus". A proposed precisification of what Coady has in mind is that the first kind of moralism involves assuming that something that might make a positive contribution to the realization of something morally worthy has that positive effect under all conditions; the second kind of moralism is condemning or appraising an action without taking due account of its predictable consequences. Of course, the two moralisms are related. If you engage in absolutist moralism because you assume all actions or properties of a certain type are under all circumstances worth protecting, fomenting, or restricting, you are vulnerable to engaging in moralism of unbalanced focus, because you are likely not looking at the predictable consequences, good or bad, of that action in the circumstances in which it is being deployed.

This paper begins with a critique of the libertarian conception of freedom of expression in section one. In the second section, the paper continues with a criticism of the liberal conception of freedom of expression. In the third section, the paper identifies distinguishing features of the democratic conception of freedom of expression. Finally, the paper concludes.

\section{Libertarian Freedom of Expression}

In 1972 Scanlon published a seminal paper defending an unrestricted content-libertarianism. Scanlon claimed that content should never be restricted in virtue of the message it carries. The content of each and every expression is sacrosanct. Any person has the right to express any content, and the content of expression should be unlimitedly protected against the claim that it leads people to have false beliefs and to cause people to do harm. Scanlon synthesizes his 1972 view through the Millian Principle:

There are certain harms which, although they would not occur but for certain acts of expression, nonetheless cannot be taken as part of a justification for legal restrictions on these acts. These harms are: a) harms to certain individuals which consist in their coming to have false beliefs as a result of those acts of expression; b) harmful consequences of acts performed as a result of those acts of expression, where the connection between the acts of expression and the subsequent harmful acts consists merely in the fact that the act of expression led the agents to believe (or increased their tendency to believe) these acts to be worth performing (Scanlon, 1972: p. 213).

As Scanlon notes, key to this conception is that it does not talk directly about the views it might allow restriction over, but rather it references the justifications that could not be employed to restrict them. There are various internal problems with this view, in that it prohibits the legitimate measures Scanlon and relevant other parties to this debate accept. For instance, Scanlon believed that it is "obvious that this principle is compatible with acceptable reasons for restricting expression” grounding, for instance, defamation laws, laws against assault involving successful communication of a threat, laws against widely disseminating scientific knowledge of how to make very harmful bombs that would require little effort to fabricate, and even laws that would prevent a person from deceitfully yelling "Fire!" in a theater (Scanlon, 1972: pp. 210-211).

One might add false advertisement, perjury, fraud, murder through the use of deceit, malpractice expressed in a medical opinion and academic plagiarism as legitimate no-go zones for freedom of expression on the grounds of their harmful consequences and/or their tendency to lead others to believe harmful actions to be worth performing. Scanlon believed we could have our cake and eat it too: endorsing a theory that gives us simultaneously our reasonable grounds for legitimate limits and an unrestricted protection for the flow of any and all ideas at the same time. The obvious thing about this set of contentions is, of course, that it is not consistent. Defamation laws are justified because of the harmful false beliefs they generate, at the unjust expense of the target of defamation. Laws against expressions constituting a type of assault are justified precisely because they generate harmful states of mind, causing you, for instance, to have to let go of your belongings because the expressions of the thug made you believe that this was indeed worth doing. Cogent arguments of this kind in certain situations in favor of certain restrictions of freedom of expression are obviously going to apply. But a consistent application of the Millian principle would, of course, rule out such reasonable legitimate restrictions.

To focus on a more controversial case, given, for instance, that reputation matters significantly to a person's livelihood and professional development, it seems reasonable that the law should protect us from people who wish to take away our deserved respect and recognition through slander. Defamation laws, like other lower level laws that guarantee the right of freedom of expression, have a grounding in human rights codes. Article 22 of the Universal Declaration of Human Rights states that everyone has the right to uphold and protect their dignity. And perhaps more explicitly, Article 12 says that "No one shall be subjected to arbitrary interference with his privacy [...] nor to attacks upon his honour and reputation. Everyone has the right to the protection of the law against such interference or attacks." Article 21 specifies the right that the authority of government is the will of the people, chosen through free elections. If lies on a massive scale violate the right of the people to freely will their choice for government, then those lies are not a right, since deceived choice is not free choice. With few exceptions, all countries have signed and ratified the International Covenant on Civil and Political Rights, which through Article 17, virtually repeats verbatim Article 12 . Further, the covenant specifies in Article 19 that:

Everyone shall have the right to freedom of expression; this right shall include freedom to seek, receive and impart information and ideas of all kinds [...] The exercise of [these] rights... carries with it special duties and responsebilities. It may therefore be subject to certain restrictions, but these shall only be such as are provided by 
law and are necessary... [f] or respect of the rights or reputations of others; [among others].

With the exception of the United States and Canada, ${ }^{4}$ virtually all countries of the Americas have ratified the American Convention on Human Rights, which through Article 13 guarantees the right to freedom of expression by claiming the universal right to freedom of research, opinion, expression and thought in any medium. It says that people are free to exercise this right until it becomes an encroachment on the rights and reputations of others. The natural reading of such statements of internationally recognized human rights with reference to dignity, reputation, and rights, involves, of course, the right of persons not to have other agents fabricate and propagate significantly harmful, false or negligently-verified information that negatively affects their rights. International laws and conventions are of course natural places to begin to seek for potential justification of regulation, and were created and are used for that purpose. Unlike Scanlon's theory, international law seems in this respect quite clear and consistent. It states that you do have the rightful freedom of expression to disseminate information until the point at which your expression is an abusive infringement on the rights of others. People have a right to be protected by law against abuses of the type that constitute an illegitimate interference with their liberty and are, consequently, acts of domination.

Scanlon's basic justification for the Millian Principle is that one must respect people's autonomy. Scanlon states that the restriction on falsely claiming there to be a fire is compatible with the Millian Principle, clarifying that his reason is the "recognized fact that under certain circumstances individuals are quite incapable of acting rationally” (Scanlon, 1972: p. 220). Additionally, he says that it is only in a far-fetched sense that the people who are prevented from hearing the false shout would be prevented from making up their own mind, the diminished capacity of the audience is brief and would apply to anyone in similar circumstances, and there would be a unanimous consensus in restricting this expression. ${ }^{5}$ I'll make two points. First, while these may be good grounds for restricting the expression, they could only not be so if the (likely) result of the expression were harmful or damaging. When we have just opened our eyes in the morning, we have a brief moment where rational capacities are diminished, but that does not warrant the restriction that no one be able to offer us a cup of coffee. At least part of the justification for the restriction on the expression in question is that it will predictably cause false beliefs that will lead people to think performing harmful actions are worthwhile. Secondly, it is not true that everyone would agree with the restriction. For one, the man doing the shouting would not agree to having his freedom of expression, as he might conceive of it, being restricted in this way. There will also be a group of people who might agree with him as a means to support their vested interests, for instance, some newspapers owners who might profit from the event or the owners of other theaters who might see this event as giving their theaters a market advantage.

The supposed consensus that everyone would agree on this restriction would only be among a group of people who want to

\footnotetext{
${ }^{4}$ Multilateral Treaties. Department of International Law. Organization of American States. Verified 29 Aug. 2012,

http://www.oas.org/dil/treaties_B-32_American_Convention_on_Human_R ights_sign.htm

${ }^{5}$ Scanlon (1972: p. 220) cites Dworkin (1971) for developing these criteria.
}

prevent lies or negligent falsehoods from having unreasonably high human costs. In making a responsible decision one should consider net human rights losses. In terms of autonomy, it cannot be said that no expressions adversely affect it. One cannot say that one is selling organic apples when they are full of DDT or arsenic, without negatively affecting the autonomy of people fooled into eating them. And, conversely, one cannot legally or acceptably launch a campaign to make people believe that a company that sells organic apples actually sells apples full of DDT or arsenic. Such contents of expression diminish the autonomy of people, both individually and collectively. Further, the integrity of the system of autonomous, efficient and just decision making in the economic realm is in conflict with misinformation. Fraud and false advertisement are good permanently restricted expressions. ${ }^{6}$ While a consensus is too demanding a criterion, it is not unreasonable to suppose that the vast majority of people will agree on this, and that the prevention of fraud, defamation, assault, false advertisement, perjury, plagiarism, is actually a government-backed enhancement of autonomy. Expressions of these types illegitimately and adversely affect the autonomy and human rights that democratic governments should protect at all times. This makes the libertarian conception of the right of freedom of expression appear self-undermining.

In correspondence, Noam Chomsky has indicated to me that the Millian Principle is OK. ${ }^{7}$ This is quite coherent with other things he has said on the subject. The division of the kinds of expressions that Chomsky holds as relevant is that between expressions one approves of and those one does not approve of. The true defender of the right of freedom of expression, according to Chomsky, holds that each person should be able to express any content whatsoever he or she considers worth expressing. He says:

It is a truism, hardly deserving discussion, that the defense of the right of free expression is not restricted to ideas one approves of, and that it is precisely in the case of ideas found most offensive that these rights must be most vigorously defended. Advocacy of the right to express ideas that are generally approved is, quite obviously, a matter of no significance (Chomsky, 1980).

For Chomsky, the legitimate existence of libel laws is questionable, so I will not focus on them here. ${ }^{8}$ However, what should be uncontroversial is that fraudulent and other expressions suggested to be in the no-go zone should not be tolerated. What exactly constitutes fraud is well-understood for a portion of cases. When an advertisement tells you that the company is selling you apples, without telling you that they are poisoned (or has failed to adequately check, when it does), it has committed a kind of fraud or false advertisement, and laws should and do exist to give some legal protections for citizens to defend themselves against this kind of deception. But similarly, if a newspaper finds it profitable to deceive people into thinking that a genuine organic apple company actually sells poisoned apples, this should not be allowed. These are instances of views whose expression are not protected by the right of freedom of expression.

To just say that the right of freedom of expression allows

\footnotetext{
${ }^{6}$ More on related issues in Stiglitz (1999; 2000).

${ }^{7}$ Email correspondence, 16 October, 2011.

${ }^{8}$ Email correspondence, 16 October, 2011.
} 
anyone to make any expression in any context, especially in those instances we disapprove of, unduly collapses what we treasure as humans into one and only one all-extensive, but self-undermining, human right that extends over all spheres of action. This attitude, in light of the examples discussed, betrays an absolutist moralism by assuming that the libertarian right will always have a positive effect, when there are clear types of cases where it does not. Further, the attitude exemplifies a moralism of unbalanced focus by failing to look at the predictable consequences of putting the Millian Principle into practiceone of whose practical consequences will itself be a negative effect on the right of freedom of expression. To illustrate, people who were fooled into eating apples with arsenic by being told that they were organic where denied their right to express their genuine preferences and had their lives, and consequently their opportunities for expression, illegitimately shortened. It is clear that this argument, like any other, can be abused and one must beware not to do so. But to put the libertarian conception of the right of freedom of expression into practice is too blunt to be close to respecting autonomy, free choice in a democratic society and the right to know information of public interest.

\section{Liberal Freedom of Expression}

Scanlon's 1979 theory of freedom of expression carves out categories of expression which require different treatment, determined by three kinds of expressive interests (participant, audience, and by-stander interests) and by available forms of regulation. Scanlon's view is that:

while it is legitimate for the government to promote our personal safety by restricting information about how to make your own nerve gas, [it is] not legitimate for it to promote our safety by stopping political agitation which could, if unchecked, lead to widespread social conflict. I do not think that my judgment in the latter case rests simply on the...idea of that the bad consequences of allowing political controversy will in each such case be outweighed by the good... The difference [between the two cases is] that where political issues are involved governments are notoriously partisan and unreliable. Therefore, giving government the authority to make policy by balancing interests in such cases presents a serious threat to particularly important and audience interests [...] (Scanlon, 1979: p. 534).

What is the relevant political speech? Scanlon says that it is that which "has to do with the electoral process and activities of government". The other categories of content that are protected are religious speech, sexual, and others that cannot be reliably distinguished from them, and would consequently harm our expressive interests (Scanlon, 1979: pp. 522, 534, 539). Since Scanlon thinks that what he is doing in the 1979 modification of his 1972 theory is to constrain the scope of his earlier theory (Scanlon, 1979: p. 536), it seems that it must be that selected categories are those to which the Millian Principle applies. This is content-liberalism.

First, Scanlon's approach has it that the theory should be "consistent with our policy", and therefore takes for granted that the current information system is quite appropriate and, consequently, that the status quo is the way things ought to be, or pretty close (Scanlon, 1979: p. 550). I do not think this is so and will come back to this issue. Secondly, Scanlon's theory implicitly hinges on a division of the relevant stake-holders as that between people and the government. This division exists, but it blurs important facts about the realities of power. In some countries, it is private power that is most menacing against our liberties and state action is the way in which oppressed groups can enforce their rights. Some governments are elected precisely to challenge large dominating powers that have taken over state and private levers of illegitimate power. We must remember, for instance, that from Haiti to the Andes and the United States it was the state that abolished slavery. Even though the state had been an enforcer of slavery in the past, the state played a significant role in the conditions that brought about its abolition. In some cases, arbitrary power outside the state is just as powerful as the state itself and is even able to command the state through de facto means. ${ }^{9}$ Policy-makers elected on the ticket of challenging those powers can hardly be said to constitute the relevant powers against which people are contrasted. If the media is owned by large vested interests in maintaining a certain political lie, then a government by and for the people will do right, subject to a standard of proof, to hold those media companies accountable. Thirdly, laws against certain political deceitful information offer a way for people to defend themselves against government abuse.

Let me first make the point about principle here by highlighting certain kinds of political expression that are undeserving of unlimited protection precisely because of their harmful consequences: 1) Vote counters lying in an election about the number of votes they count, leading to illegitimate leaders; 2) Someone lying under oath that they saw Martin Luther King murder an innocent white child; 3) Issuing racist threats that impede the black vote or blacks running for office; 4) Lying to the people and policy-makers as to why a country should go to war with deceitful pictures and supposed eyewitness accounts of threatening weapons of mass destruction; 5) Verbally threatening a person so as to prevent her from running for public office; 6) Defaming a political opponent through the lie that he or she ordered the murdering of innocent civilians in order to give the appearance of legitimacy to a coup; 7) In serious conversation with an assassin, saying "Kennedy and Castro are pawns of communism. I'll give you $\$ 1,000,000$ to make it worth your while to kill them next year”.

It might be objected that these expressive acts should be banned, not because of their content, but because of the way they are expressed. It might well be that whispering the wrong vote-count when nobody hears or when it has negligible risk, should not be restricted. But the way example 1 was put, is that it actually leads to an undemocratic result, violating the right of freedom of expression of voters. If the democratic system operated in such a way as to block this potential result in time, and found the culprit, then it would seem correct to hold that person accountable to justice. There should be institutional safeguards against people who follow Stalin's commonly attributed maxim that "those who cast the vote decide nothing. Those who count the votes decide everything". Those who lie about the vote numbers are the true violators of the right of freedom of expression of the people-not the people who would hold them accountable. People who follow the liberal conception of the right of freedom of expression would be barred from prohibiting certain acts of election fraud, since if fraudulent political

\footnotetext{
${ }^{9}$ In capitalism, government is bought by the big market players (Ferguson, 1995; Lessig, 2011).
} 
expression by certain people were to be realized, as might well have been the case in the United States elections of 2000 and Ohio of 2005 (Toobin, 2002; Crispin, 2005), then such agents could never be held to account for stealing a democracy from a country. On item 2 it seems clear that it is the expressing of the content itself to defame Martin Luther King and the black liberation movement under oath that is a problem. On item 3 it seems clear that the content of the threat is what is problematic, as it is, in effect, an unjust impediment to the exercise of the right of free expression of blacks. Case 4 is troublesome precisely because of the deceitful content that would enable politicians to go to war, having also as a corollary thousands of lost liberties, of which the right of freedom of expression would have to be included. Thus, on the decision side, it would create a policy (going to war) that is not a true exercise of the right of freedom of expression of the people the government is supposed to represent; and on the receiving side of the war of aggression, the thousands of murdered people would see their rights of freedom of expression, along with every other right, severely negatively and undeservingly affected by injury, disease and death. If there were no law to hold officials who lie to go to war accountable, then you sever the rightful interests of the nation from the interests of the politician, and wars of aggression would become more frequent. It would not be a violation of George W. Bush's right of freedom of expression to be charged with murder because of the lies he used to bring about the United States' invasion of Iraq (Bugliosi, 2008). The violation here is not of Bush's right to free expression-it is of the thousands of Iraqis and US soldiers silenced by their wrongful deaths brought about by the content of Bush's statements. The content of Bush's expressions, because of their consequences, is what makes them worthy of restricting. Case 6 is somewhat controversial, but I think it is correct. Political opposition is an expressive right that needs to be protected. The integrity of the system of free competition is sustained by the reliability of the system to track better political alternatives. This cannot be done in a system where significant lying about opponents is protected-much in the same way that if it were acceptable for companies to lie about their competitors, fair competition could not be produced, whether by market standards or relevant alternatives.

This issue will strike a chord with people knowledgeable of Latin American politics, who understand that the media have a played an important role in recent coups d'etat against democratically elected governments. ${ }^{10}$ This is not surprising, given that the mass media in Latin America has frequently been born with dictatorships, sometimes with CIA funding and infiltration, and have hidden and supported massive human rights violations. Today, the Inter American Press Association headquarters is named after the US Pentagon and CIA intelligence officer, Jules Dubois (Armoa, 2012; Kornbluh, 2003; Lagos, 2009;

\footnotetext{
${ }^{10}$ In the Venezuelan case, for instance, the media was the mouthpiece of the rise of the brief business and military dictatorship of 2002. The coup plotters publicly thanked the media when they thought they had ousted Chávez. The media justified the coup by falsifying footage to supposedly show a Chávez supporter shooting innocent civilians. See Jones (2007), Bartley and O’Briain (2003), Palacios (2004), Fairness and Accuracy in Reporting (2002). In September 2010, President Rafael Correa of Ecuador was gased and shot at in a police revolt that called for his assassination. He took refuge in a hospital (Muñoz, 2011). The media propagated the idea that this was a minor exercise in the freedom of expression of a sector of the population (Paz y Miño, 2011).
}

Mönckeberg, 2009; Blaustein \& Zubieta, 1998; Lacunza \& Becerra, 2012; Crewdson \& Treaster, 1977). It will also strike a chord with those who see the structural features of the US mass media which have provided it with an enabling role for war and rights violations against US official enemies (Chomsky \& Herman, 1988/2002). Any clear-eyed perspective on this reality will have to confront the dilemma of whether or not democracy-and-rights-undermining deceit should be checked by a democratic state.

In correspondence, Chomsky has provided me with a slightly weaker picture of the class of protected acts which should result from a theory of freedom of expression. ${ }^{11}$ The relevant distinction, under his version of the liberal conception of the right of freedom of expression, is not between statements one likes and one doesn't like, but between statements which form a part of imminent criminal acts and statements which don't. The right of freedom of expression is the right a person has to make any statement as long as that statement does not participate in an imminent criminal act. Of course, one might object that even Stalin would hold this view, since dissident statements of whatever sort constituted, by the applicable laws, immanent criminal acts. Consequently, this view seems to suffer from Chomsky's own critique of any conception of the right of freedom of expression that does not recognize the unqualified holiness of content. Recall that Chomsky said that:

Goebbels was in favor of free speech for views he liked. So was Stalin. If you're really in favor of free speech, then you're in favor of freedom of speech for precisely the views you despise. Otherwise, you're not in favor of free speech. $^{12}$

By the same standard, you might say in terms of statements made as part of immanent criminal acts, that Goebbels was in favor of free speech for those statements that are non-criminal, and so was Stalin. If you are really in favor of free speech, then you're in favor of freedom of speech precisely for those expressions which constitute a crime. Otherwise, you're not in favor of free speech, the reasoning would incorrectly conclude.

The reasoning engages in absolutist moralism since it presumes that the ideals of the right of freedom of speech will be achieved by the state never intervening in the content of expression just as it might interfere to block poisonous apples from entering the market. Disregard for the predictable consequences of cases $1-7$, undermining the very functions that give the right of freedom of expression value, reveal a moralism of unbalanced focus.

\section{Democratic Freedom of Expression}

This section progressively descends from some proposed aspects of democratic theory to the proposed conception of the right of freedom of expression. The democratic freedom of expression starts by recognizing that everyone's human rights are the same and must consequently be given equal consideration. In giving people's human rights equal consideration, attention must be given to whether there is domination in the relations that exist in society. When there is domination, it is legitimate to intervene to abolish it. The freedom that comes with individual and collective autonomy, entails responsibil-

\footnotetext{
${ }^{11}$ In email correspondence, October 16, 2011.

${ }^{12}$ Appears making the statement in Achbar and Wintonick (2002).
} 
ity. ${ }^{13}$ Thus, liberty is not an arbitrary power, but an accountable one. The democratic state is an effective instrument for protecting and fomenting human rights, abolishing domination. Such a state exemplifies the democratic ideal of equal consideration in the vote, whose spirit is the supremacy of the public interest over powerful religious, royal, military, capitalist, party or other special interests.

The natural application to the right of freedom of expression is that everyone has this right equally and that this right comes with the responsibility to respect the rights of others. When expression is an instrument of domination, it is outside the scope of this right, it infringes on the rights of others, which must be given equal consideration, and it is necessary to hold the agent that propagated the expression responsible by standards of justice.

A very good system for giving everyone equal consideration is the democratic one. This practice is designed to approximate the principle of affected rights. The rights-based approach has it that voting is designed to approximate the principle that people whose rights are at stake in a matter are the ones who should participate in the decision-making process associated with it. Rights have the rights of others as their common boundary and transgression of these boundaries is an act of domination. Rights are legitimate liberties, which are the kinds of liberties worth protecting and fomenting, and are consequently the kinds of liberties we refer to below. Here, the degree to which there is liberty in a population is inversely proportional to the degree to which there is domination.

\section{Liberty with Interference}

One of the most emphasized elements of the republican theory of freedom and government is that interference, even coercive interference, is not always a real reduction of freedom and that sometimes there is non-interference in the absence of freedom (Pettit, 1997). This is one of the features that distinguish republicanism from liberalism, which holds, in Bentham's words, that "no liberty can be given to one man but in proportion as it is taken from another. All coercive laws, therefore... and in particular all laws creative of liberty, are, as far as they go, abrogative of liberty" (Bentham, 1843: p. 503 cited in Pettit, 2009). The thesis that sometimes coercive interference contributes to liberty, is classically illustrated by the story of Ulysses interfering in various ways so that the sirens do not deviate his ship from its destiny. A more contemporary example illustrating the thesis is that of appropriate traffic regulation, backed by penalties for non-compliance. A good reason for the penalties is that they will tend to override people's temptation to run a red traffic light. Such measures can hardly be said to curtail the human right of freedom of movement. Quite to the contrary of considered alternative views, such short-term limits of movement in the considered cases enable the right of movement to be most effectively realized, thus contributing to freedom. It is a condition to enable Ulysses and lawful drivers to get to their destination in the fastest, safest, and most coordinated way. In the republican mode of thought, barring other possible interfering circumstances, Ulysses and the drivers are not dominated

\footnotetext{
${ }^{13}$ Although today's conceptions of autonomy and freedom can never be as metaphysically robust as Kant's (1964/1785), that they be conditions for self-determination that confer responsibility for an action should be reflected in any theory that values freedom and autonomy (Kane, Fischer, Pereboom, \& Vargas, 2007).
}

by an external source of arbitrary power. As Blackstone says in his 1765 Commentaries on the Laws of England, republicanism holds that "laws, when prudently framed, are by no means subversive but rather introductive of liberty" (1978: p. 126). Rightful freedom, the kind of freedom that is relevant, is freedom with brains.

The democratic republican will interfere where government is needed to eliminate domination, the opposite of rightful freedom, and will use majority rule to do it. It may well be necessary at times to go deep, to "go into people's bedrooms", for instance, to eliminate marital rape. In practice, this idea can be abused and we must guard against its being used for arbitrary interference, which would be a form of domination.

Condorcet’s (1785/1972) and Arrow’s (1951/1963) impossibility theorem may give the impression that majority decisions are arbitrary, and consequently constitute acts of domination. Dilma prefers A to B and B to C; Rafael prefers B to C and C to A; Hugo prefers $C$ to $A$ and $A$ to $B$. Each person will express their preferences in their vote, pitting two options first, and the winner of that vote with the remaining option, second. This class of preferences does not yield a consistent aggregate majority decision which can represent the common good and the ordering can be manipulated to yield the false appearance of an authentic majority preference for any option. Very skeptical attitudes about majority government can be adopted in light of this truth. For instance, Rousseau's contention, under one interpretation, that the general will tracking the common good is expressed by the balance of pluses and minuses with respect to a decision (Rousseau, 1762/2008: p. 34), seems inapplicable. But what the theorem actually proves is that there is a class of combinations of ordered preferences which do not uniquely express a social welfare function. This class, however, is very small with respect to the field of decision space to which majority rules can be applied, and constitutes only a small cost to the power of majority rule for representing the common good. For comparison, our visual system has an area of the visual field that is "filled in" because of the blind-spot generated by the optical nerve entering our eyes (Ramachandran, 1992). In this space, our eye cannot be said to be genuinely detecting the external properties we seem to see. Instead, our brain fills in this space. But no one would recommend that we stop using the visual system to represent the world and guide our behavior. Likewise, that for some small portion of possible cases (Tangian, 2000; Mackie, 2003; Shapiro, 2003) majority decisions are filled in is an affordable price, given the alternatives and the general capacity of majority government to represent the common good. ${ }^{14}$ Rather than get stuck on a decision not based on picking up the properties of the common good or give the reins of power to a dictator, the majority fills in those places where voting cycles occur and otherwise reliably track the common good in the rest of the decision space.

Madison, one of the prime architects of minority veto-powers of the founding fathers of the state of the US, after having the experience of a lifetime in high-office, took his famous design back when he said:

If majority governments as such, be the worst of governments, those who think and say so cannot be within the

\footnotetext{
${ }^{14}$ Tversky (1969) has argued that individuals have this kind of irrationality. Regenwetter, Davis-Stober and Dana (2011) dispute this. But even if Tversky were correct that individuals under certain circumstances are systematically irrational, this is far from showing wholesale irrationality and the unreliability of our psychology, as argued by Hilary Kornblith (1993).
} 
pale of the republican faith. They must either join the avowed disciples of aristocracy, oligarchy or monarchy, or look for a Utopia exhibiting a perfect homogeneousness of interests, opinions \& feelings nowhere yet found in civilized communities (Madison, 1833/1834).

While Madison's democratic credentials are tainted with his participation in slavery, an issue that reportedly troubled his perspective on the nation (McCoy, 1989: p. 252), his rejection of the idea that the best government is that which cancels out majority decisions with minority vetoes, provides some ground for democratic optimism. To let minorities veto majority rule is to in effect strongly bias the status quo and the de facto powers that entrench it. With the great problems of our time, letting the entrenched non-democratic powers continue to determine the way our society functions is a great irresponsibility. From an empirical standpoint, majority governments have typically been the most respectful when it comes to individual and minority rights (Shapiro, 2003a).

Contrary to content-libertarianism and liberalism, certain regulation in content may likewise further free and fair discussion and expression, this being so because majority rule will be able to track the genuine common good in this realm more reliably. In turn, the general will identified through majority rule must be based on truth, and for this, adequate epistemic conditions need to be in place. As Madison famously said:

A popular government without popular information or the means of acquiring it is but a prologue to a farce or a tragedy, or perhaps both. Knowledge will forever govern ignorance: And a people who mean to be their own Governors, must arm themselves with the power which knowledge gives (Madison, 1822).

So, what are the best mechanisms for securing this condition? One proposal is the marketplace of ideas. The democratic conception of freedom of expression will analyze and build from it.

\section{Non-Interference without Liberty}

That "the marketplace of ideas" is the best mechanism for securing individual and collective autonomy and a knowledgeable citizenry, approximating adequate capacities of good decision-making and representing the common good, is a prima facie plausible idea and a key proposal for the treatment of the right of freedom of expression. For some sections of opinion, such prescriptions cohere with a general distrust of the state's ability to do good, be efficient, just, and be party to truth. In fact, the idea takes root in some popular conceptions of modern economics that hold that minimal state participation produces efficient results. When put this way, a market free of an active state role produces efficiency, typically measured in terms GDP growth, but can also include poverty reduction and human development. In the realm of expression, a market of ideas very free from an active state role produces efficient results selecting for the expressive basis of autonomy, knowledge and good political decision-making. The story is attractive, but hides just as important aspects of what an efficient economy worth having requires.

Minimally, the neoliberal experience should be a warning against the completeness of this picture. It hides the role that the state must play in development, in not letting economic elites take oligarchical or monopoly power over some sectors of the economy and not let those elites take over the informational and political system, undermining democracy. In a democracy, it is people who rule; not capital. Failure to act on this has led to a very negative influence on economic development itself, economic growth, employment, has increased poverty and inequality, and has decreased human development, freedom and rights in countries as diverse as the United States, Chile, Ecuador and Argentina, and far beyond (Kornbluh, 2003; Lagos, 2009; Sen, 1999; Weisbrot \& Ray, 2011; Chang, 2007; Baker, 2002; Meller, 2000). Failure to act on the idea that people should govern rather than capital, has led to a real reduction in freedom of expression in Ecuador, for instance, because most of the media has been largely owned by banks (Checa Godoy, 2012).

The right of freedom of expression, particularly of the press, is of course a key instrument when it comes to attaining truths of public significance. But we can ask whether the market model of the press, a concrete corollary of a natural reading of "the marketplace of ideas" thesis, is efficient with respect to truthful states of mind about matters of public interest and which affect people's autonomy. Here the market model does not measure up very well. Curran, Iyengar, Lund and Salovaara-Moring compared the US media market model with the UK media mixed model, and the Finnish and Danish public service model of the media, with respect to how well informed inhabitants in each of these different media environments were about the world in which they live (Curran, Iyengar, Brink Lund, \& Salovaara-Moring, 2009; Aalberg, Aelst, \& Curran, 2010). They found the market model to be the worst performer with respect to producing any kind of knowledge and found that it is particularly bad, when compared with the others, at maximizing knowledge of public interest among the population. In this study, the political questions of public interest were relatively straightforward. For example, one of them asked the participant to name the president of France. Incidentally, 67\% of US respondents got the answer to this question wrong, even with the advantage of having multiple choice options (Curran, Iyengar, Brink Lund, \& Salovaara-Moring, 2009). This kind of easy "hard news" question was significantly better answered by the public where the media regime was more public service oriented and less market-driven.

The most powerful and the most active country in international affairs had the least proportional foreign news coverage. The most covered issue was Iraq (47\% of international news, which was $20 \%$ of total news) (Curran, Iyengar, Brink Lund, \& Salovaara-Moring, 2009), an issue about which the public has been deeply deceived, in the service of promoting a war with massive human rights violations (Fairness and Accuracy in Reporting, 2007; World Public Opinion, 2004, 2006). ${ }^{15}$ This fact confirms, again, Chomsky's and Herman's Propaganda

\footnotetext{
${ }^{15}$ This analysis is very much in line with what Russell theorized when he said: "Since the running of a big newspaper requires a large capital, the proprietors of important organs necessarily belong to the capitalist class, and it will be a rare and exceptional event if they do not sympathize with their own class in opinion and outlook. They are able to decide what news the great mass of newspaper readers shall be allowed to have. They can actually falsify the news, or, without going so far as that, they can carefully select it, giving such items as will stimulate the passions which they desire to stimulate, and suppressing such items as would provide the antidote. In this way the picture of the world in the mind of the average newspaper reader is made to be not a true picture, but in the main that which suits the interests of capitalists" (Russell, 1918/2002: p. 95). It is also very much in line what Oscar Romero, the Salvadoran liberation theologian, explained before being killed by right-wing death squads in 1980: "It is a pity that we have a media system so sold out to the conditions. It is a pity that one cannot trust the news of the newspapers, the television and the radio because everything is bought, everything is rigged, and truth is not told”.
} 
Model of the US media, which predicts, given the economic and institutional structure of that information system, that the media will largely disseminate information that serve the interests of certain economic and military groups at the expense of the public interest and human rights (Chomsky \& Herman, 1988/2002). This is, of course, an act of domination against the people, severely negatively affecting autonomy, knowledge and democratic decision-making.

"Non-intervention" on expression is a choice that favors the players and views that dominate the communication space today. In some instances the source of this status quo is anything but legitimate-one example of this, is that El Mercurio of Chile would not have the kind of media and market power it has were it not for the CIA and dictatorship financing and approval (Kornbluh, 2003; Crewdson \& Treaster, 1977). Non-intervention in similar cases, including cases where media companies have been instruments of coups against democratic governments, amounts to a form of domination (Jones, 2007; Bartley \& O’Briain, 2003; Palacios, 2004; Fairness and Accuracy in Reporting, 2002; Muñoz, 2011; Paz y Miño, 2011; Miguel Armoa, 2012; Kornbluh, 2003; Lagos, 2009; Mönckeberg, 2009; Blaustein \& Zubieta, 1998; Lacunza \& Becerra, 2012; Crewdson \& Treaster, 1977). Adequate democratic intervention in such cases makes responsibility effective. A classic example in the non-domination literature is that of the slave who has learned the desires of his master so well, that the master need not intervene in the behavior of the slave. Nevertheless, the master holds an arbitrary and illegitimate power over the slave, amounting to a form of domination. In such cases where domination is the status quo, the state may intervene to abolish it.

The present consideration unveils a certain naiveté or bias towards the status quo on the part of the Inter American Commission for Human Rights Freedom of Expression Rapporteurship for claiming that while journalism needs to be ethical, the state cannot make policy to ensure it and that any state-led initiative to tilt the expressive system towards truth and public service goes against the right of freedom of expression. ${ }^{16}$ Indeed, this is like reiterating the falsehood that the state does not have a role in securing economic efficiency and human rights.

One feature of the irony of free speech that Fiss noted is the fact that scarce space for expression means that more actual expression is less of other potential expression (Fiss, 1996). The natural conclusion that Fiss drew was that while the state can harm freedom of expression, it can also have a legitimate role in affecting content so that there is a genuine democratic discussion of issues of public interest. Applying this idea to the facts on the ground, one may note the further irony that the scarce space of communication is so frequently dominated by views so effective at threatening and undermining human autonomy, democratic decision-making and the right to know crucial matters of public interest.

The Millian idea that the people should allow media carte blanche to say whatever they wish and that from that we can decide on issues for ourselves is in this context deeply naïve, because it effectively leaves the microphone in the hands of people who deprive the public of vital information and spin information towards human rights abuses. This non-interference by a democratic power has not worked in the interests of liberty and has involved much domination, adversely affecting

${ }^{16}$ Principles 6 and 7 of the Principles of the Right of Freedom of Expression of the Inter American Commission on Human Rights. individual and collective autonomy, informed decision-making in democracy and the right to know facts of public relevance. It is therefore a legitimate place for democracy to exercise its rightful and intelligent power to abolish this tyranny.

\section{Democratizing Content}

Several features of a media system supporting, rather than hindering, autonomy, informed democratic decisions and knowledge of public issues, and thus fulfilling the requirements of the right of freedom of expression, can be noted. One is that the empirical evidence shows that a robust public service media is a crucial component of a society that values the right of freedom of expression. In a dictatorship, the media financed by the state may be subservient to interests undermining the right of freedom of expression. However, in a society with greater democratic institutions, public service media enhances rather than diminishes the fulfillment of the right of freedom of expression (Curran, Iyengar, Brink Lund, \& Salovaara-Moring, 2009; Aaelber, Aelst, \& Curran, 2010).

It is important to eliminate the conflict between serving business interests and providing information for adequate democratic decision-making. The fact, for instance, that there should be mass media companies in the United States owned by arms companies (such as GE and Westinghouse) and financial elites that profited from the economic mismanagement of the recent years, can only seem coincidental to the naïve. Better information would have made making war and building an \$8 trillion bubble more difficult. There are other features, such as limiting the market share a media company or conglomerate may have. An experiment being tried in some countries of South America is to divide the television and radio electromagnetic spectrum into three equal parts, those being for private, public and community ownerships. Regulation in campaign finance so that people can really be autonomous knowledgeable agents participating rationally in the democratic process, rather than be manipulated by the moneyed or other interests, is a feature of conditions that truly honor the right of freedom of expression. A system where rational choice theory is made Ptolemaic, as Ferguson (1995) has described it as applied to the US political system, ${ }^{17}$ is one which undermines, rather than respects, the right of freedom of expression of people. There are various alternatives within this option (Lawrence, 2011; Rowbottom, 2010), but the driving consideration is that autonomous self-determining people do the talking, rather than peopled flooded by party propaganda or the interests of capitalists. This is true autonomy and self-determination.

The democratic conception of freedom of expression recognizes the following territories of expression as legitimately restricted: false advertisement, perjury, fraud, medical opinion constituting malpractice, academic plagiarism, electoral deception, or expressions that result in murder, either by the hiring, ordering or fooling of someone in such a way that it leads, intentionally or negligently, to illegitimate death, or by intentionally and illegitimately causing grave harm to another with the use of expression-such as kindly offering (poisoned) coffee as an expression of political dissent. Such acts are against the rights of people and therefore constitute acts of domination,

\footnotetext{
${ }^{17}$ Although Citizens United v. Federal Election Commission is not as radical as it is sometimes made out to be (Levitt, 2010), it is another recent brick on the wall that serves to keep knowledgeable, rational and autonomous expressions of the people from controlling their state.
} 
undermining autonomy, democracy and knowledge. It is for this reason that towards the end of the Universal Declaration of Human Rights, Article 29 says that "In the exercise of his rights and freedoms, everyone shall be subject only to such limitations as are determined by law solely for the purpose of securing due recognition and respect for the rights and freedoms of others and of meeting the just requirements of morality, public order and the general welfare in a democratic society".

Similarly, Article 13 the American Convention on Human Rights restricts expressions that infringe on the rights of others, constituting propaganda for war or hate speech. The more controversial sorts of limits on the right of freedom of expression are honor and national security. These issues have to be dealt with carefully because of the risk that they be abused against the rights of others. One fundamental way in which the values that uphold the right of freedom of expression are secured is by vigorously defending the right to criticize the actions of others, whether in public office or not. A strong investigative press, with strong guarantees, is required for expressive action against domination. There are also easy cases that avert us to the abuse of this freedom. It is easy to think of a case where a person decides, with a deep, connected and communicative pocket at hand, to ruin the honor of another for no good reason, resulting in unjust social, psychological and economic pain. While there need to be measures to avert the possibility that powerful groups abuse libel laws to eliminate legitimate opponents with a robust and competent public defense system, people need to have good protection against libelous kind of domination.

New York Times Co. v. Sullivan established the importance for being guilty of libel of actually malicious intent of false damaging statements against someone. However, this is consistent with rules that make democracy work, in symbiosis with autonomy, informed decision-making and knowledge. In the case of commercial markets, lies and negligent falsehoods by a company to make people believe that their adversary is selling poisoned apples as organic ones, is reasonably disallowed. Groups competing for political power in the democratic process, whether directly or indirectly, should be subject to the same honesty constraints, if the decisions by voters are going to truly express their autonomous non-manipulated views. The libertarian and liberal conceptions of freedom of expression, however, could never condemn a malicious lie to hurt a legitimate market or political competitor, and secure basic rules that ensure the integrity of economic and political competition.

A recent and much-publicized case involved the president of Ecuador, Rafael Correa, who sued Emilio Palacio for lying in one of Ecuador's biggest daily, El Universo. Palacio (2011) wrote that Correa, "the dictator", had committed "crimes against humanity" by "ordering shooting against a hospital full of civilians and innocent people”. It is, of course, of public concern if a head of state has committed crimes against humanity. But Palacio was given all the opportunities to show a shred of evidence for his strong statement of public interest, but constantly said that support for his statements was "not the issue". The real issue, according to Palacio, was his right to say whatever he wanted. Human rights NGO's and, both national and international media, generally defended what they termed Palacio's and El Universo's right to express their view. Expression with malicious intent, which was given documentary support in the accusation, and its effect on what is treasured in the right of freedom of expression, and the right against abusive attacks on one's reputation, were not considered. ${ }^{18}$ In the political realm this is important precisely because people vote for politicians based on their reputation with respect to whether they will advance their rights and well-being, and thus worthy of authorizing their representation. We can see from this that they seem to have employed the libertarian and liberal conceptions, rather than the democratic one.

Perhaps the foregoing discussion has elicited the suggestion that the proposal made here is restrictive. However, the standards used have strong implications for the duty of the state to release information of public interest and the right of journalists to publish it. It is not legitimate, on national security grounds, to hide information about the crimes that the state and its agents commit in the name of the people. To hide such information is an act of domination against the people the state represents since the state is violating their right to control government and their right and responsibility to respect the rights of others. It is also, of course, an act of domination against the victims of the crime. Such acts of domination reduce autonomy, knowledge and informed decision-making in democracy. The people that reveal such secret crimes are protected by the right of freedom of expression.

The libertarian, liberal and democratic conceptions of the right of freedom of expression would all imply protection for people who use their freedom of expression to reveal crimes and operations of public interest of the state. There is, for instance, no legitimate reason for a state to hide that it bombed North Vietnam, Laos and Cambodia before the public knew about it, as the Pentagon Papers revealed, or that a president was expanding the war on Vietnam when he was telling the public that there is no such intention or that the war on Vietnam officially begun based on deceit about the Tonkin Gulf incident (Martin, 2003: p. 11). It is, of course, in the interests of autonomy, informed decision-making and public knowledge that people find out that while their government was denying that there was a coup in Honduras in 2009 (McLean, Shane, \& Tse, 2011), their ambassador was internally saying that it was (Naiman, 2010 ) -which is tantamount to attempting to provide international political cover for the subversion of democracy - and it is in the people's expressive interest that they find out that their states' grounds for war were not true and that it is murdering people in Iraq in their name (Wiki Leaks, 2010). This is a national security issue, but for Laos, Cambodia, Honduras and Iraq, whose rights are served by having the information be expressed. For the United States, the national security issue is that the rights of the people are being violated by a state that does not reflect their legitimate interests and therefore their democratic nation is threatened. Thus, for the United States it is in the interests of national security that the Pentagon Papers and Wiki Leaks be expressed. For the perpetrating state, there is not legitimacy in secrecy, just as there is no legitimacy in a murderer owing a gun, which a responsible citizen is correct to "steal", as Daniel Ellsberg and Bradley Manning did. This means, for instance, that they, along with Julian Assange, and organizations like Wiki Leaks, are bastions of the right of free-

\footnotetext{
${ }^{18}$ See for instance, Human Rights Watch (2011); Washington Post (2011); El Universo, 2012 offers a catalogue of papers that republished the lies of Palacio's article, for freedom of expression. Palacio and El Universo were declared guilty, which carried a disproportionately large fine and a jail term. Correa pardoned them and the penalties were voided and not executed. In the spirit of this paper, I think Palacio and El Universo should have had to incur a proportionate cost geared towards appropriate reparations for the damage they inflicted.
} 
dom of expression that need to be protected. Interestingly, generally the mass media has been quite aggressive against Assange. The mass media did the same as he, which was to make the information public (except when it touched their interests (Lacunza \& Becerra, 2012)), because it was a scoop too big to leave to the competitors, but adopted a hostile position at the first opportunity. The dominant narrative became that he is a sex assailant information thief, granted asylum by a repressive nation, who will pay a just price for its lack of obedience to global powers (e.g. El Comercio, 2012; EFE \& El Universo, 2012; Washington Post, 2012; Vargas Llosa, 2012 The Economist, 2012; Córdoba, 2012; Naureckas, 2011). Taking into account that the Iraq war was a corporate media driven event, it is easy to conclude that these powers defend, in their actions, their supposed right to dominate, frequently at the cost of the three pillars of values that uphold the right of freedom of expression. The law in democracy should protect the people's right to freedom of expression.

\section{Conclusion}

Libertarian and liberal freedom of expression advocates must make a decision about whether they just care about the idea of anyone being able to say whatever they want, letting the chips fall where they may, with no regard to the relations of power and whether the subsequent consequences undermine their simple categorical imperative, or whether they care about the protection and enhancement of human rights and the values that actually sustain the a right of freedom of expression worth having. The democratic theory of freedom of expression says that people have the right to express any view they may wish to express that does not constitute an act of domination against another. The right of freedom of expression is for abolishing domination, not for enhancing it. The effective idea that the right of freedom of expression is that a person can say whatever she wishes for whatever reason or lack of reason, and in whatever context, including deceit that costs us our human rights is very much like the argument of white male slave-owners who argued that abolishing slavery would violate their constitutional and human right to property. There have, of course, to be limits to the right of ownership of a person, and those are the rights of others. The democratic conception recognizes such legitimate limits-which in turn advance net human rights, including rights of expression. A single person and her rights cannot count less or more than the rights of another, as the democratic tradition emblematically recognizes at least since Locke. A law limiting an individual's freedom in this way enhances the freedom of the people, both individually and collectively. This is very much in line with the word and spirit of the Universal Declaration of Human Rights and the American Convention of Human Rights, but not so much with the corporate structure and practice of our prevailing media system.

\section{REFERENCES}

Aalberg, T., Aelst, P., \& Curran, J. (2010). Media systems and the political information environment: A cross-national comparison. The International Journal of Press/Politics, 15, 255-271. doi:10.1177/1940161210367422

Achbar, M., \& Wintonick, P. (2002). Manufacturing consent: Noam Chomsky and the media. New York: Zeitgeist Video.

Armoa, M. (2012). Los propagandistas del régimen Stroessner.

http://ea.com.py/los-propagandistas-del-regimen-de-stroessner/
Arrow, K. (1951/1963). Social choice and individual values. New Haven: Yale University Press.

Baker, D. (2002). The run-up in home prices: Is it real or is it another bubble? Washington DC: Center for Economic and Policy Research.

Baker, D. (2011). The end of loser liberalism: Making markets progressive. Washington DC: Center for Economic and Policy Research.

Blaustein, E., \& Zubieta, M. (1998). Decíamos ayer: La prensa Argentina bajo el proceso. Buenos Aires: Colihue.

Bentham, J. (1843). Anarchical fallacies. In The works of Jeremy Bentham: Published under the superintendence of his executor, John Bowring. Vol. 2. Edinburgh: William Tait.

Blackstone, W. (1978). Commentaries on the laws of England. New York: Garland.

Bartley, K., \& O’Briain, D. (2003). The revolution will not be televised. Bórd Scannán na hÉireann, Nederlandse Programma Stichtin, Radio Telefís Éireann, British Broadcasting Corporation, Zweites Deutsches Fernsehen, Arte, Yleisradio, Power Pictures 2002 Ltd.

Braddon-Mitchell, D., \& West, C. (2004). What is free speech? Journal of Political Philosophy, 12, 437-460. doi:10.1111/j.1467-9760.2004.00208.x

Bugliosi, V. (2008). The prosecution of George W. Bush for murder. New York: Vanguard Press.

Chang, H. (2007). Bad samaritans: The myth of free trade and the secret history of capitalism. New York: Bloomsbury Press.

Checa Godoy, A. (2012). La banca y la propiedad de medios: El caso de Ecuador. Revista Latina de Comunicación Social, 67, 125-147.

Chomsky, N. (1980). Some elementary remarks on the rights of freedom of expression. In R. Faurisson (Ed.), Memoire in defense. http://www.chomsky.info/articles/19801011.htm

Chomsky, N., \& Herman, E. (1988/2002). Manufacturing consent: The political economy of the mass media. New York: Pantheon Books.

CNN (2012). http://www.youtube.com/watch?v=0eyj30vBlao

Coady, A. (2008). Messy morality. Oxford: Clarendon Press.

Condorcet, M. de (1785/1972). Essai sur l'application de l'analyse a la probabilité des décisions rendues à la pluralité des voix. New York: Chelsea Pub. Co.

Crewdson, J., \& Treaster, J. (1977). CIA established many links to journalists in US and abroad. New York Times, 27 December 1977. http://jfk.hood.edu/Collection/Weisberg\%20Subject\%20Index\%20Fi les/C\%20Disk/CIA\%20Reporters\%20New\%20York\%20Times\%20S eries\%2012-25-77/Item\%2001.pdf

Crispin, M. (2005). None dare call it stolen: Ohio, the election and America's servile press. Harper's Magazine. http://harpers.org/archive/2005/08/0080696

Curran, J., Iyengar, S., Brink Lund, A., \& Salovaara-Moring, I. (2009). Media system, public knowledge and democracy: A comparative study. European Journal of Communication, 24, 5-26. doi: $10.1177 / 0267323108098943$

de Córdoba, J. (2012). Ecuador takes the stage with asylum offer. The Wall Street Journal. http://online.wsj.com/article/SB100008723963904440829045776074 30333300126.html?KEYWORDS=assange

Dworkin, G. (1971). Paternalism. In R. Wasserstrom (Ed.), Morality and the law. Belmont: Wadsworth Pub. Co.

Editorial Board (2012). Ecuador gambles on Wiki Leaks founder assange. Washington Post.

http://www.washingtonpost.com/opinions/ecuador-gambles-on-wikil eaks-founder-julian-assange/2012/08/20/1a6b4ca2-e8b0-11e1-936ab801f1abab19_story.html

El Comercio (2012). Diarios internacionales coinciden en que asilo a Assange es paradójico.

http://www.elcomercio.com/politica/Comercio-Lima-Rafael-Correabuen-dictador-prensa-internacional-medios_0_759524095.html

EFE \& El Universo (2012). Washington Post advierte que asilo a Assange podría traer consecuencias económicas desastrosas a Ecuador.

http://www.eluniverso.com/2012/08/21/1/1355/washington-post-alert a-quito-consecuencias-comerciales-caso-assange.html

The Economist (2012). An Ecuadorean history of the world. http://www.economist.com/node/21560881

Fairness and Accuracy in Reporting (2002). US papers hail venezuelan 


\section{R. RESTREPO}

coup as pro-democracy move.

http://www.fair.org/index.php?page=1867

Fairness and Accuracy in Reporting (2007). Iraq and the media.

http://www.fair.org/index.php?page=3062

Ferguson, T. (1995). Golden rule: The investment theory of party competition and the logic of money-driven political systems. Chicago: Chicago University Press.

Fiss, O. (1986). Free speech and social structure. Yale Faculty Scholarship Series, 1210.

http://digitalcommons.law.yale.edu/fss_papers/1210

Fiss, O. (1996) The irony of free speech. Cambridge, MA: Harvard University Press.

Human Rights Watch (2011). Ecuador: A blow to free speech. http://www.hrw.org/news/2011/07/21/ecuador-blow-free-speech

Jones, B. (2007). Hugo! The Hugo Chávez story from mud hut to perpetual revolution. Hanover: Steerforth Press.

Kane, R., Fischer, M., Pereboom, D., \& Vargas, M. (2007). Four views on free will. Oxford: Blackwell.

Kant, I. (2002/1785). Groundwork for the metaphysics of morals. In T. E. Hill Jr., \& A. Zweig (Eds.), A. Zweig (Trans.), Groundwork for the metaphysics of morals. New York: Oxford University Press.

Kenney, K. (2004). How free is the press in Ecuador? Public Library of US Diplomacy.

https://www.wikileaks.org/plusd/cables/04QUITO2740_a.htm

Kornblith, H. (1993). Our native inferential tendencies. In A. Goldman (Ed.), Readings in philosophy and cognitive science. Cambridge, MA: MIT Press.

Kornbluh, P. (2003). The Pinochet File: A dossier of atrocity and accountability. Washington DC: National Security Archive.

Lacunza, S., \& Becerra, M. (2012). Wiki Media Leaks. Buenos Aires: Ediciones B.

Lagos, C. (2009). El diario de Agustín: Cinco estudios de caso sobre El Mercurio y los derechos humanos. Santiago: Lom Ediciones.

Lessig, L. (2011). Republic, lost: How money corrupts congress and a plan to stop it. New York: Twelve.

Levitt, J. (2010). Confronting the impact of Citizens United. Yale Law and Policy Review, 29, 217-234.

Mackie, G. (2003). Democracy defended. Cambridge: Cambridge University Press. doi:10.1017/CBO9780511490293

Madison, J. (1833/1834). Memorandum on “majority Government”. In G. Hunt (Ed.), The writings of James Madison. http://memory.loc.gov/cgi-bin/query/r?ammem/mjmtext:@field(DO CID+@lit(jm090149))

Madison, J. (1822). Letter to W. T. Barry. August 4.

Martin, B. (2003). The Legacy of the Pentagon Papers. The Whistle, 34, 11.

McCoy, D. (1989). Last of the fathers: James Madison and the republican Legacy. Cambridge: Cambridge University Press.

McLean, A., Shane, S., \& Tse, A. (2011). Analyzing a coup in Honduras. New York Times, 19 June 2011.

Meller, P. (2000). The Unidad Popular and the Pinochet dictatorship: A political economy analysis. London: Palgrave Macmillan. doi:10.1057/9780230523951

Mill, J. S. (1789/1975). On liberty. In Mary Warnock (Ed.), Utilitarianism (126-250). Glasgow: Collins/Fontana.

Mönckeberg, M. (2009). Los magnates de la prensa. Santiago: Debate.

Muñoz, R. (2011). Muchedumbre 30S. Quito: Video Documental.

Naiman, R. (2010). Wiki Leaks Honduras: State Department Busted on Support of Coup. Huffington Post, 29 November 2010. http://www.huffingtonpost.com/robert-naiman/wikileaks-honduras-st ate_b_789282.html

Naureckas, J. (2011). When journalism becomes terrorism. Fairness and Accuracy in Reporting. http://www.fair.org/index.php?page $=4247$

Palacio, E. (2011). NO a las mentiras. El Universo. http://www.eluniverso.com/2011/02/06/1/1363/mentiras.html

Palacios, A. (2004). Puente Llaguno: Claves de una masacre. Caracas: PanaFilms.
Paz y Miño, I. (2011). Falsos positivos: Visiones del 30S en cuatro periódicos Ecuatorianos. Quito: Pontificia Universidad Católica de Ecuador.

http://puce.the.pazymino.com/IsabelPyM_FalsosPositivos.pdf

Pettit, P. (1997). Republicanism: A theory of freedom and government. Oxford: Oxford University Press.

Pettit, P. (2009). Law and liberty. In S. Besson, \& J. L. Martí (Eds.), Law and republicanism. Oxford: Oxford University Press. doi:10.1093/acprof:oso/9780199559169.003.0002

Ramachandran, V. S. (1992). Filling in the blind spot. Nature, 356, 115. doi:10.1038/356115a0

Regenwetter, M., Davis-Stober, C., \& Dana, J. (2011). Transitivity of preferences. Psychological Review, 118, 42-56.

doi:10.1037/a0021150

Rowbottom, J. (2010). Democracy distorted. Cambridge: Cambridge University Press.

Rousseau, J. (1762/2008). The social contract. New York: Cosimo, Inc. Russell, B. (1918/2002). Proposed roads to freedom. University Park, PA: Pennsylvania State University.

Toobin, J. (2002). Too close to call. New York: Random House.

Scanlon, T. (1972). A theory of freedom of expression. Philosophy and Public Affairs, 1, 204-226.

Scanlon, T. (1979). Freedom of expression and the categories of expression. Pittsburgh Law Review, 40, 519-550

Sen, A. (1999). Development as freedom. Oxford: Oxford University Press.

Shapiro, I. (2003a). The state of democratic theory. New Haven, CT: Yale University Press.

Shapiro, I. (2003b). The moral foundations of politics. New Haven, CT: Yale University Press

Shapiro, I. (2011). The real world of democratic theory. New Haven, CT: Yale University Press.

Shapiro, I. (2012). On non-domination. University of Toronto Law Journal, 62, 293-336.

Stiglitz, J. (1999). On liberty, the right to know, and public discourse: The role of transparency in public life. Oxford Amnesty Lecture.

Stiglitz, J. (2000). The contributions of the economics of information to Twentieth Century economics. Quarterly Journal of Economics, 115 , 1441-1478. doi:10.1162/003355300555015

Tangian, A. (2000). Unlikelihood of Condorcet's paradox in a large society. Social Choice and Welfare, 17, 337-365. doi:10.1007/s003550050024

Tversky, A. (1969). Intransitivity of preference. Psychological Review, 76, 31-48. doi:10.1037/h0026750

El Universo (2012). NO a las mentiras se reproduce en varios medios de América Latina.

http://www.eluniverso.com/2012/02/23/1/1355/no-mentiras-reproduc ira-medios-impresos-america-latina.html

Vargas Llosa, M. (2012). Julián Assange en el balcón. El País. http://elpais.com/elpais/2012/08/24/opinion/1345819181_800344.ht $\mathrm{ml}$

Washington Post (2011). Ecuador's autocrat cracks down on media freedom. 28 July 2011. http://www.washingtonpost.com/opinions/ecuadors-autocrat-cracksdown-on-media-freedom/2011/07/27/gIQA5BRtfI_story.html

Weisbrot, M., \& Ray, R. (2011). The scorecard on development, 19602010: Closing the gap? Washington DC: Center for Economic and Policy Research.

Wiki Leaks (2010). Collateral murder. http://www.collateralmurder.com/

World Public Opinion (2004). Americans continue to believe Iraq supported Al-Qaeda, had WMD.

http://www.worldpublicopinion.org/pipa/articles/international_securi ty_bt/100.php?nid=\&id=\&pnt=100

World Public Opinion (2006). Percentage of Americans believing Iraq had weapons of mass destruction rises.

http://www.worldpublicopinion.org/pipa/articles/brunitedstatescanad ara/238.php 